\title{
Idiopathic Acquired True Leuconychia Totalis and Partialis: A Rare Case Report
}

\section{Shikha Verma and Binod Kumar Thakur*}

North Eastern Indira Gandhi Regional Institute of Health and Medical Sciences, Shillong, India

\section{Keywords: Leuconychia; Nail disorder; Parakeratosis}

Idiopathic acquired true total leukonychia is a rare condition, with only a few reported cases. We hereby report a rare case of Idiopathic Acquired True Leuconychia Totalis and Partialis in a 24 -year-old healthy male.

The patient presented to Dermatology Out Patient Department with whitish discolouration of all fingernails for 5 years and few toe nails for 2 years. He initially noticed partial synchronous whitish discolouration of all fingernails which gradually involved the entire nail plates resulting in total leuconychia. After 3 years, he also observed partial whitish discolouration of few of the toe nails. There was no history of trauma, drug intake and exposure to chemical agents or significant illness. The patient had no central nervous system, eye, ear, hair, teeth, or skin abnormalities. There was no family history of skin or nail disease and the patient were born to non consanguineous marriage. The general and systemic examination revealed no abnormality. On local examination, total leuconychia of all the finger nails and partial to total leuconychia of all the toenails was seen (Figures 1 and 2). The periungual areas were healthy. Complete hemogram, liver and kidney function tests were within normal limits and ELISA for HIV test was nonreactive. Repeated potassium hydroxide preparations and fungal cultures of the white nails were negative. The patient was advised for follow up to see any further increase in toenail leuconychia.

Leuconychia was first described by Mees in 1919, as an associated finding in arsenic intoxication [1]. The condition can be either true leukonychia, with involvement of the nail plate, or pseudoleuconychia, caused by subungual and nail bed abnormalities. In true leuconychia, the nail plate appears white as a result of abnormal matrix keratinisation. The nail plate has a normal surface but loses its transparency and looks white because of the presence of parakeratotic cells within its ventral portion. Parakeratotic cells have immature large nucleus which has keratohyalins in it. The cells that have keratohyalin reflect the light and the nail seems white [2].

Leuconychia may be acquired, inherited or rarely, idiopathic. Acquired leuconychia is frequently associated with trauma, drugs, systemic or local infections such as typhoid fever, hepatic cirrhosis, ulcerative colitis or leprosy, hypocalcaemia and very commonly minor trauma. True leuconychia can be inherited as an isolated condition or

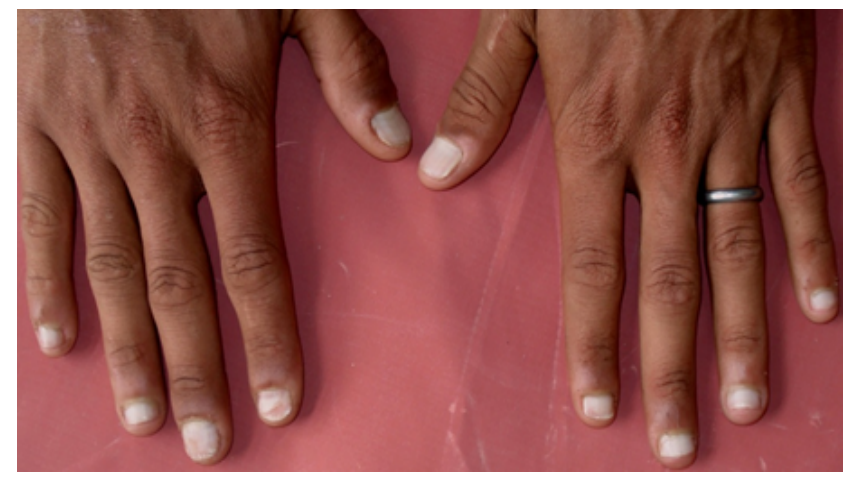

Figure 1: Total leuconychia of fingernails

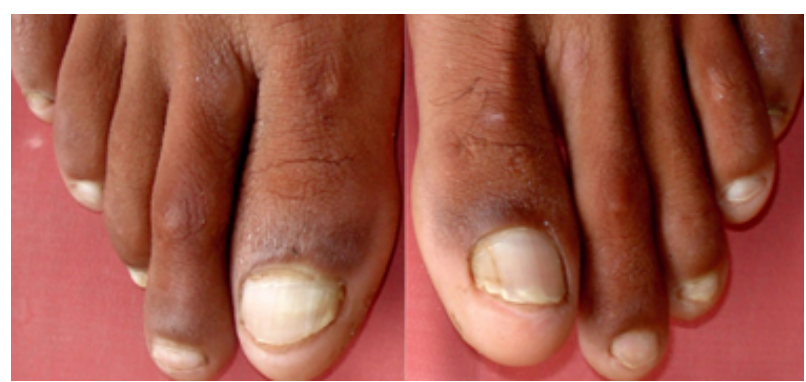

Figure 2: Partial to total leuconychia of toenails

may be associated with diverse clinical conditions like palmoplantar keratoderma and atrophic fibrosis, pili torti [3], congenital hypoparathyroidism, hypoparathyroidism, onychorrhexis, cataract, and the LEOPARD syndrome. Our patient was healthy and no such association was noticed in our case.

To our knowledge, only ten cases of idiopathic, acquired, true total leuconychia are reported till date in literature $[4,5]$ amongst them there was only one Indian patient [4]. We are hereby reporting the second Indian patient with idiopathic, white fingernails and toenails without any hereditary cause. The knowledge of this rare entity is important to reassure the patients who are disturbed by whitish discolouration of the nails.

\section{References}

1. Mees RA (1919) Een verschijnsel bij polyneuritis arsenicasa. Nederlands Tijdschrift voor Geneeskunde 1: 391-396.

2. Tosti A, Piraccini BM (2003) Nail disorders. Dermatology, Mosby, Philadelphia USA: $1061-1078$

3. Giustina TA, Woo TY, Campbell JP, Ellis CN (1985) Association of pili torti and leukonychia. Cutis 35: 533-534

4. Arsiwala SZ (2012) Idiopathic acquired persistent true partial to total leukonychia. Indian J Dermatol Venereol Leprol 78: 107-108.

5. Dlova NC, Tosti A (2014) Idiopathic acquired true total and subtotal leukonychia: report of two cases. Int J Dermatol 53: e261-263.
*Corresponding author: Binod Kumar Thakur, Department of Dermatology and STD, North Eastern Indira Gandhi Regional Institute of Health and Medical Sciences, Shillong, India, Tel: +919774165590; E-mail: binod.k.thakur@gmail.com

Received July 07, 2014; Accepted September 19, 2014; Published Septembe 21,2014

Citation: Verma S, Thakur BK (2014) Idiopathic Acquired True Leuconychia Totalis and Partialis: A Rare Case Report. Pigmentary Disorders 1:135. doi:10.4172 JPD.1000135

Copyright: @ 2014 Verma S, et al. the terms of the Creative Commons Attribution License, which permits unrestricted use, distribution, and reproduction in any medium, provided the original author and source are credited. 